\title{
THE POETRY OF EASTERN EUROPEAN IRELAND: STEREOTYPES AND APPROPRIATIONS
}

\author{
JERZY JARNIEWICZ
}

\section{Introduction}

In 1988, towards the close of the turbulent decade, which in Northern Ireland started with the drama of hunger strikes and in Poland with the strikes in Gdańsk dockyards, the foundation and subsequent suppression of "Solidarity", Seamus Heaney published The Government of the Tongue, his controversial critical book centered on the question of the poet's, and poetry's, responsibilities in a world of suffering and social injustice. In these polemical essays Heaney put forward an image of Eastern European poetry as the exemplary literature not only to be studied, but also to be followed. Heaney discussed at length the works of such poets from beyond the Iron Curtain as the two Poles, Czesław Miłosz and Zbigniew Herbert, the Russian Osip Mandelstam, and the Czech poet, Miroslav Holub.

\section{Heaney and his construct of Eastern European poetry}

Heaney has no knowledge of Polish or Russian. His acquaintance with Polish, Russian or Czech poetry is necessarily mediated through English translations. However attentive a reader he may be, he cannot address the works of these European poets in their full cultural and historical contexts. Yet this hardly seems a serious drawback, since when Heaney writes about Eastern Europeans, it is Irish poetry that he has primarily in mind. Heaney is not an ambassador of Polish or Russian poetry, keen on promoting it abroad, but an Irish poet looking for inspiration also beyond the English speaking world and, what is even more important, for arguments supporting his own poetic choices. As I will try to argue, his image of Eastern European poetry is to a considerable extent his own construct.

In one of the essays Heaney famously paraphrases Stephen Dedalus' comment written on April, 3 in his diary from The Portrait of the Artist as a Young Man:

I am reminded of Stephen Dedalus's enigmatic declaration that the shortest way to Tara was via Holyhead, implying that departure from Ireland and inspection of the country from the outside was the surest way of getting to the core of Irish experience. Might we not nowadays affirm, analogously, that the shortest way to 
Whitby, the monastery where Caedmon sang the first Anglo-Saxon verses, is via Warsaw and Prague? (Heaney 1988: 40-41)

Heaney changes the Irish context of Joyce's (or Stephen's) formula and instead speaks of England and English literature, claiming that the shortest way to Whitby is through two Eastern European capitals. It should be noted that Heaney not only changes the legendary Irish city for the English location, but also replaces what in Joyce's dictum was the national, political centre by the place of origins of English, or Anglo-Saxon verse. Whitby, as he reminds his readers, is the site where Caedmon composed his first songs, and hence where English poetry started. The difference is clear: whereas Joyce was speaking of a nation or race, Heaney is interested in arts. And asks a question: what is it that would make English-language poetry more pertinent to modern experience? The answer is: translation, the impulse coming from Eastern Europe, from Warsaw and Prague.

The reason why Heaney chooses Eastern European poetry as the frame of reference for English, or Anglo-Saxon, poetry is both surprising and predictable: the high moral and aesthetic quality of Eastern European verse is - in his eyes the function of its external political context, the context of repressions and of revolts against these repressions. It follows that the poetry from beyond the Iron Curtain, which Heaney proselytises for, can allegedly revitalise contemporary British verse, since the East Europeans have witnessed, and reflected in their arts, the horrifying experiences of the twentieth century.

This invigoration is needed because of "the insular and eccentric nature of English experience: England's island status, its off-centre European positioning, its history of non-defeat and non-invasion since 1066" (Heaney 1988: 41). Heaney seems here to follow the romantic idea that great poetry capable of addressing fundamental issues can emerge only in the cultures exposed to the horrors of history. English poetry had no such historical experience to reflect upon, contrary to the poetry written beyond the Iron Curtain, and, Heaney suggests, in Northern Ireland. Thus Eastern European poetry, Polish poetry included, serves Heaney in a twofold manner: firstly, it validates the stance taken by him and other poets of Northern Ireland, and secondly it provides him with an important argument in his critique of the stagnation of contemporary British verse. As Justin Quinn (2009: 104) remarks:

Heaney's engagement with poets from Eastern Europe has been extremely varied from the 1970s to the present, but it has never been merely a niche interest of his; rather, their examples helped him at crucial junctures of his career, as he reacted to, and indeed helped create, cultural politics in Ireland during the last three decades.

The central essay of The Government of the Tongue, "An Interesting Case of Nero, Chekhov's Cognac and the Knocker”, starts with a scene set in Belfast of 
1972, in which Heaney and his friend, musician David Hammond, are on their way to the studio to record a song, but in the meanwhile they hear bombs exploding. In the studio they discover they cannot sing, as they believe joyful singing would be an offence to human suffering which these bombs signify. This conflict, which Heaney calls "song vs. suffering" or "art vs. life", illustrates a nearly archetypical situation in which the Northern Irish poet has often found himself, torn between the two seemingly opposite poles of aesthetics and ethics. Some poets, like Wilfred Owen, who faced similar tension, sacrificed poetry in the name of truth: "Above all I am not concerned with Poetry," - Owen famously declared - "My subject is War, and the pity of War. The Poetry is in the Pity" (Owen 1994: 98).

Yet Heaney, though experiencing directly the tragedies of the Troubles, is far from giving up the song and following Owen's denial of poetry. Art, or singing, as a joyful celebration of life cannot yield to the tyranny of history. To support those poets, who like himself in spite of suffering compose and sing, Heaney gives examples of Eastern European poets. Though living under pressure, they could sing - without compromising themselves. Eastern European poets, such as Zbigniew Herbert, seem to work as arguments in Heaney's discussion of his role as the poet in the war-torn country. Towards the end of his essay, Heaney arrives at a point when he says "I'm inclined to think that if Herbert had been in the studio with us in 1972, he would have encouraged us to stay and make the tape" (Heaney 1988: xix). Thus Zbigniew Herbert becomes "one of us": he is a poet who would show solidarity with the Northern Irish poets of the Troubles and endorse Heaney's moral and aesthetic choices.

\section{Northern Ireland and Poland: The tragedy of the 1980s}

As I have remarked, Heaney offered his readings of Eastern European poetry in the 1980s - the decade equally tragic for both countries, Ireland and Poland. In Poland it was the time of martial law, the suppression of Solidarity, internment, political persecutions, street riots. In Ireland it was the time of hunger strikes and their repercussions such as marches, assassinations, bomb attacks. Both Poland and Northern Ireland were countries under siege and torn by violence. Both had interesting poets who asked themselves Hölderlin's famous question: Wozu Dichter?

It is no wonder than that both countries inspired each other. Heaney and his fellow poets looked up to Polish poets as models of how to act in the state of political pressure; and in Poland, as Piotr Sommer testified, contemporary poets learnt "from the careful weighting of the personal and the political to be found in Ulster poetry" (O’Driscoll 2001: 97). There were Irish poets of the Troubles, like Heaney and Tom Paulin, who followed Polish poets, and practiced the art of the parable so generously represented by Herbert, Holub or Sorescu; there were Polish poets of martial law, like Piotr Sommer and Bohdan Zadura, who followed 
Irish poets of the Troubles and wrote poems set in a clearly marked political context, yet remaining private in their voice, cadences, and diction. A way was open for cross-fertilisation and a firm belief in the affinity between the two cultures emerged.

It is significant that the only Irish poets translated at that time into Polish were the poets of the Troubles, poets from Northern Ireland. Similarly, the only Polish poets translated and discussed by Irish poets were poets of dissidence associated with the opposition to the communist rule. Beyond the pale, beyond the sphere of interest of Irish poets and critics, were Polish poets who ignored the political context and, for example, concentrated on the issues of language, such as Wat, Wirpsza, Karpowicz, Białoszewski.

But let us return to Heaney's essays from The Government of the Tongue. Having described and praised Polish poets for their ability to retain artistic and ethical integrity in the times of historical chaos, Heaney explains the reasons of choosing to write about them. The reason is the similarity between the situations in Poland and in Ireland:

I keep returning to [poets from Eastern bloc countries] because there is something in their situation that makes them attractive to a reader whose formative experience has been largely Irish. There is an unsettled aspect to the different worlds they inhabit, and one of the challenges they face is to survive amphibiously, in the realm of 'the times' and the realm of their moral and artistic self-respect, a challenge immediately recognizable to anyone who has lived with the awful and demeaning fact of Northern Ireland's history over the last couple of decades" (Heaney 1988: xx).

It is a revealing passage. As Heaney wants it, one of the aspects that makes Eastern European poets attractive is "something in their situation", i.e. the political context in which they live, the context of oppression and suffering, or to quote Heaney's words once again, "the awful and demeaning facts of [national] history". Heaney offers here an analogy between Eastern bloc countries, with their history of opposition to the inhuman political system, and Ireland of "sectarian prejudice, discrimination in jobs and housing, gerrymandering by the majority, a shared understanding that the police were a paramilitary force" (Heaney 1988: xxi).

This analogy between Poland and Ireland has become a mental-image, a cultural stereotype. As any analogy, it points to objectively verified realities of likeness, as much as it omits important differences. For example, it leads to assuming that Britain played a similar role in Irish history that Soviet Russia played in the history of Poland, and that British imperialism had its counterpart in communist ideology. These wide-spread assumptions have been questioned by Jan Jędrzejewski, who claims that if there is any correspondence between IrishBritish relationship on the one hand and Polish history on the other, then Poland 
could be seen more like Britain than Ireland, as in the past it politically and culturally annexed its Eastern territories, the so-called Borderland ("Kresy"), whose history may be seen as an Eastern European equivalent of the history of British presence in Ireland. Jędrzejewski's revisionist reading challenges the commonly held presumption that "Britain is to Ireland what Russia is to Poland" (Jędrzejewski 2008: 93). His reading changes the usual way of looking at Poles as innocent victims and provocatively makes them, makes us, play the role of the British to the true Eastern European Irishmen: Byelorussians, Lithuanians, and Ukrainians.

\section{Critique of Heaney's Irish-Polish analogy}

Doubt as to the adequacy of Heaney's analogy was expressed also by an Irish poet, critic, and Heaney's friend, Dennis O’Driscoll:

It would be an absurdity to make any direct comparison between post-1969 Northern Ireland and pre-1989 Eastern Europe. Over 3,000 people died in the Ulster Troubles and many more lives have been blighted by the conflict. However, the deplorable repressions and discriminations endured by Northern Irish Catholics were never on a scale remotely comparable with those suffered by people under various Communist dictators (O’Driscoll 2001: 98).

O'Driscoll's reservations pertain to the number of victims: what may worry him is that the analogy might support the strain of martyrdom in Irish nationalism. The parallel does not pass muster because we did not suffer that much, O’Driscoll seems to claim. He may be right, but a question remains, however, whether or not a poet living in the Republic, as O'Driscoll does, can justifiably weigh the suffering of the people from Northern Ireland.

A different critique of Eastern European-Irish analogy came from another Irish poet and critic, Gerald Dawe, who wrote:

Despite Heaney's thoughtful and sensitive reading of Eastern European poets, the question arises: is there not to be found in Italy or Spain a more apt connection with Ireland, with the cultural and moral dominance of an ultra-conservative church, a society politically divided by civil war, parochially partisan and conforming to populist images of itself? Perhaps a Passolini or Lorca may have more to offer by way of artistic and critical analogy than a Mandelstam or Milosz. In terms of 'the North', with which The Government of the Tongue begins, are not imaginative contexts more readily available closer to home, in Scotland, for example, rather than in Zbigniew Herbert's Poland? For the problem of cultural identity in Scotland relates directly and historically to the conflict between political nationalism and religious patriotism on a scale more in keeping with our history than, say, the struggles of Poland (Dawe 2000: 144). 
Dawe, a poet of Protestant background, who edited an anthology of the Protestant writing in modern Ireland, takes a different political stand than Heaney, distancing himself from what he believes to be Heaney's nationalism emerging in his Ireland-Poland analogy. Further on in his essay Dawe (2000: 144) writes:

The real distinctions emerge from the relationship between poet and state in
Eastern European and Soviet societies. Mandelstam or Akhmatova, Milosz or
Herbert, relate 'oppositionally' to the cultural orthodoxies and beliefs of their
countries. This cannot be said of contemporary Irish poets, because they are
essentially insiders since little separates them from the cultural idealism of which
their poetry and the historic Irish nation are assumed to be part, a point which
many observers of contemporary Irish literature seem to ignore. Obviously this
puts under strain any analogy between Eastern European and Irish poetry.

Dawe's claim is interesting in offering a different perspective on Irish culture, and specifically on Irish poetry, which according to him shows greater similarity with Spain or, for different reasons, Scotland. Yet, there is also a hidden agenda in Dawe's offering of these new analogies, which are in fact no more justified, nor more objective than Heaney's. If Dawe speaks here of Spain, it is because - in contrast to Heaney - he wants to see the Irish Troubles as civil war rather than the effect of a history of foreign colonial rule. Moreover, his critique of Heaney's appropriation of Polish and Russian poets, however benign this appropriation is, has an underlying intention, which is to criticise Irish poets for their inability to oppose their cultural orthodoxies, something which in the eyes of Dawe, Polish poets do. "Whatever unease Heaney may or may not feel about Ireland we live in, does not surface in his poetry. There is an acceptance of this place as it is which ranges from the stoical to the faithful”, writes Dawe about Heaney.

Dawe's questioning of Heaney's analogy is an indirect indictment of Heaney's allegedly pious, nationalist stance, which does not allow for the renegotiation of Irish identity. Dawe seems to claim that one cannot compare Irish and Polish identities - Irish identity, as in Scotland, is split, ambiguous, and conflict ridden, which Irish poets seem to ignore. When Dawe speaks of them as part of cultural idealism he criticises the abstract, or mythical nature of the concept of Irishness to which they subscribe. The phrase "historic Irish nation", as opposed to, let's say, "Irish society today", emphasises the anachronistic character of the nationalist concept, anchored in the imaginary past and in national stereotypes.

But the analogy works also in Poland. Heaney's Polish translator Stanisław Barańczak introduced him as a familiar poet, almost a fellow countryman, whose place is alongside great Polish poets, such as Miłosz or Herbert. In his essay Barańczak admits he got interested in Heaney when he learnt that Heaney wrote about Zbigniew Herbert - a telling confession which shows, I think, that at the bottom of Barańczak's interest in Heaney was the Irish poet's "Polish 
connection”. Further on in the essay, Barańczak describes his first meeting with Heaney claiming that the two immediately found a common language, as could be expected from "representatives of two Catholic nations, wronged by history and consuming large amounts of potatoes (and their products)” (Barańczak 1995: 18). Though the comment is made partly tongue in cheek, it is significant that Barańczak uses elements of blatant cultural stereotypes about the Irish and Poles, which include their supposedly unquestioned Catholicism, their self-image as victims of history, and prominence of rural, peasant culture. Stereotypes cannot be entirely eliminated, they serve as shortcuts, without which it would be impossible to communicate. But here, in the case of a translator introducing an Irish poet, they are supposed to domesticate the poet, to show him as being "not very different from us", to make him an honorary Pole. The rhetoric of similar statements makes Ireland an Eastern European country in the West of Europe.

Another translator of Irish poetry into Polish, Piotr Sommer, assumed a different position. He found Heaney's poetry attractive not because of the supposed likeness of the two cultures, but on the contrary, because of the difference: Heaney to him was an example of an interesting Barbarian, who undermines national and cultural verities, produces antipastoral verse (Sommer 1983: 146-7). Disappointed by the state of contemporary Polish poetry, in which Herbert and Miłosz ruled, showing their anachronistic dictions, Sommer believed that Irish poets may show how to write poetry with political themes without turning it into journalism, how to address historical issues en passant and in personal terms (Sommer 2005). The Irish poets possessed the qualities which Polish poetry lacked, despite the seeming similarity of the histories of the two countries.

\section{Conclusion: The Eastern European analogy or stereotype?}

The Eastern European-Irish analogy which has been at work in the recent history of Irish poetry is not an innocent proposition. Analogies usually serve those who subscribe to them. A carefully selected comparison singles out features which are then presented as dominant, if not definitional. Analogies strengthen existing stereotypes, but they can also subvert them. The implicit aim of an analogy that puts together two cultures is primarily to perpetuate or to unsettle a mental-image of one's own culture.

The Eastern European analogy, revived by Heaney and Paulin in the 1980s, helped to consolidate the politically engaged poetry of Northern Irish poets of the Troubles and to introduce the parabolic poem associated with the poets writing in repressive systems. Heaney's Eastern European poetry was a mental construct, and as with many such constructs it is partly true, and partly his own creation, which he modeled taking into account the condition of poetry in Northern Ireland. It is more a project of analysing and reordering the poetry of his own land than a name for the writing actually produced beyond the Iron Curtain. 
It seems to be a rule that the Eastern European - Irish parallel emerges always in the times of trouble and turmoil, when political alliances need to be made. With the situation coming back to normal, the parallel disappears. Heaney still writes with admiration about Herbert and Miłosz, but significantly he dropped the term "Eastern European" - it is the individual poets and their work that he admires.

In the long run, wars, revolutions and dictatorships do not serve well the project of establishing friendly relations between cultures. Politicians come and go. Poets remain.

University of Łódź,

Poland

\section{References}

Barańczak, S., 1995, 'Wstęp. Muzyka tego, co się dzieje' [Introduction. The Music of What Happens], in: Heaney, S., 44 wiersze, Kraków: Znak, 5-18.

Dawe, G., 2000, Stray Dogs and Dark Horses. Selected Essays on Irish Writing and Criticism, Newry: Abbey Press.

Heaney, S., 1988, The Government of the Tongue. The 1986 T. S. Eliot Memorial Lectures and Other Critical Writings, London: Faber and Faber.

Jarniewicz, J., 2007, 'The Way via Warsaw: Seamus Heaney and Post-War Polish Poets', in: Crowder A. B., \& Hall, J. D., eds., Seamus Heaney. Poet, Critic, Translator, London: Palgrave Macmillan, 103-120.

Jarniewicz, J., 2009, 'The Polishing of Heaney. Seamus Heaney's Poetry in Poland: Translations, Receptions, Impact', in: Kurdi, M., ed., Literary and Cultural Relations: Ireland, Hungary and Central and Eastern Europe, Dublin: Carysfort Press, 201-216.

Jędrzejewski, J., 2008, 'Not Quite Poles Apart: Hiberno-English Literary and Cultural Relations from the Perspective of Northern Ireland', in: Klepuszewski, W., ed., The Baltic Philological Forum, Koszalin: Wydawnictwo Uczelniane Politechniki Koszalińskiej, 83-106.

O’Driscoll, D., 2001, Troubled Thoughts, Majestic Dreams. Selected Prose Writings, Oldcastle: Gallery Books.

Owen, W., 1994, The War Poems, London: Chatto \& Windus.

Quinn, J., 2009, 'Heaney and Eastern Europe', in: O’Donoghue, B., ed., The Cambridge Companion to Seamus Heaney, Cambridge: Cambridge University Press, 92-105

Sommer, P., ed., 1983, Antologia nowej poezji brytyjskiej [Anthology of New British Poetry], Warszawa: Czytelnik.

Sommer, P., 2005, 'Poeci irlandzcy, poeci polscy' ['Polish Poets, Irish Poets'], in: Sommer, P., Po stykach, Gdańsk: słowo / obraz terytoria. 